\title{
Obituary
}

\section{PATRICK ARNAUD (1939-2016)}

Patrick Arnaud was born in Paris on 27 May 1939. He completed his secondary school education at the Lycée Buffon and undergraduate studies at the Faculty of Sciences of the Sorbonne, before his doctoral studies in Biological oceanography in 1960, a field developed in France, at Marseille, by Professor Jean-Marie Pérès.

After attending a conference held at the National Museum of Natural History in Paris his future professional orientation was determined. At that meeting, Pérès read to his students a letter from the French polar expeditions organisation that offered an opportunity for a marine biologist to take part in the 1961-1963 wintering at Adélie Land in Antarctica.

His candidacy was accepted, and Patrick began his two month voyage to Antarctica in 1961 from Le Havre, onboard the Danish vessel Magga Dan.

The French base Dumont d'Urville at Adélie Land is very different today from what it was over fifty years ago. Under the generous supervision of the head of mission, René Merle, the 18 individuals wintering at that base were gathered together in one common room. The accommodation was uncomfortable, with rooms for two, and limited radio links that restricted family telegrams to only 25 words per week.

The mission was placed in jeopardy when one of the mechanics suffered from a bowel obstruction. An urgent surgical intervention was needed by the base's medical doctor, assisted by an Australian surgeon who guided the operation by radio from a distance of $2000 \mathrm{~km}$. Durmont d'Urville was not equipped with an operating room at that time, so clean sheets had to be placed around the patient to secure a sterile operating space. Assisted by the head of mission, promoted anesthetist, and the biologist as his assistant, the doctor managed to successfully operate on the patient who recovered completely and continued the wintering as planned.

Back in Marseille in March 1963, Patrick began to analyse the enormous volume of data produced during his wintering at Durmont d'Urville and two other summer expeditions at the end of 1961 and 1962. During the austral winter, he set fish traps through the sea ice and harvested numerous fish species and invertebrates (star fish, crustaceans, worms). When summer returned, the presence of Magga Dan gave Patrick opportunities to set out to the open sea in a canoe piloted by a Danish sailor. His fishing dredge could then be towed along the bottom of the sea up to $150 \mathrm{~m}$.

He returned to Dumont d'Urville in 1964 for another summer expedition to complete his dissertation research. He then obtained his Doctor of Science degree.

In the summer of 1969, he was invited onboard the French Navy's bathyscaphe Archimède that descended in the oceanic trenches of the Azores, where the cold

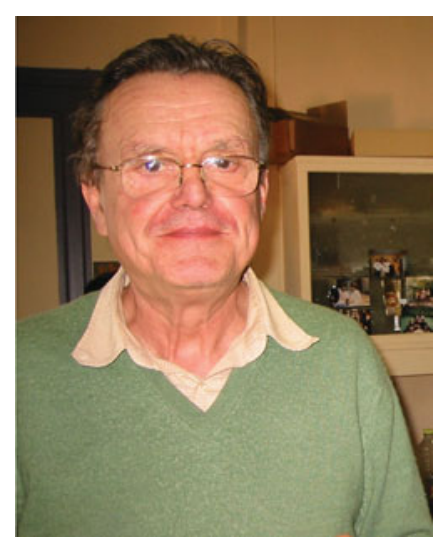

water fauna has common characteristics with that of the Antarctic waters.

He later took part in several other oceanographic missions on Marion Dufresne, a French ship that had recently been built to supply the bases of the sub-Antarctic islands, but also to explore the continental shelves of the Kerguelen, Crozet and other islands.

As a specialist of benthic fauna, his research focused on the Mollusca in the sub-Antarctic and Antarctic waters, but also elsewhere such as the Red Sea, the mangroves in Colombia and Venezuela, and also in the Mediterranean.

He also examined molluscs harvested during excavations, for example the fortification of the old port of Lacydon in Marseilles, as well as those caught and used by the Fuegian peoples either for eating or as adornments from excavations by Annette Laming-Emperaire in Patagonia.

During his career, Patrick authored nearly 200 publications.

In addition to his work, he shared his knowledge with all the foreign students he supervised (Argentinian, Chilean, Colombian, Uruguayan, etc.).

His first student - who later became a friend will always remember the help provided by Patrick, the encyclopedic knowledge he had of the marine world and the vast bibliographic scholarship he acquired throughout his career.

He published in 1967 a General bibliography of Antarctic and sub-Antarctic biology with J.-C. Hureau and F. Arnaud.

One of his important responsibilities was to oversee the pre-publication process of the newly created journal Théthys. He received from J.-M. Pérès the articles submitted to the journal for editing. He was thus always aware of the contemporary literature.

Patrick held great interest in the maritime station of Endoume, which prompted him to give an historical account of this laboratory created in 1869 and developed a few years later by Professor Marion who obtained 
authorization to construct this maritime station on a military seafront area, Arcachon and Roscoff. After his appointment in 1948, the energetic and brilliant J.M. Pérès transformed this little laboratory into a centre of French biological oceanography with over a hundred researchers.

Patrick Arnaud was a member of the Editorial Board of Polar Record for several years; his Cartesian spirit was a great asset for this peer-reviewed publication.

After 42 years of scientific work, Patrick Arnaud retired in his old house in Luberon, France. Despite his retirement, he still continued to pursue his passion for research, this time with historical findings on the Bossière brothers, pioneers of the Kerguelen Islands. He later published the Phoquiers de la Désolation, a significant contribution in collaboration with J. Beurois, P. Couesnon and J.F. Mouël.

Another book was in preparation and was almost completed by Patrick. But his brutal death at the age of 77 on 19 March 2016, after living with a painful and unknown autoimmune disease, prevented him from achieving his project.

His passing is commended by many testimonies of friendship and respect for the rigorous scientist and the generous man Patrick Arnaud has been throughout his life.

Françoise Arnaud and Jean-Claude Hureau Translated by Joël Plouffe 